\title{
A New Interpretation of Korea-Japan Relations: 'Rights Revolution' of Sex Slaves and Forced Laborers in the Courtroom
}

\author{
Ja-hyun Chun and Youcheer Kim
}

\begin{abstract}
Despite significant commonalities such as shared threat perceptions, democratic consolidation, and socioeconomic interdependence, Korea and Japan have failed to find a deeper level of reconciliation. To solve this puzzle, in this article I introduce and illuminate the features of an 'ideational reconciliation process', which captures the dynamics created by the main actors in the process - people. Through this analytical framework I explain how and why Korea and Japan failed to achieve a deep level of reconciliation by analyzing the sophisticated features of a flawed ideational reconciliation and the 'rights revolution' brought about by the sex-slave victims and forced laborers' transnational litigations. Contrary to the liberalist prediction of unconditional cooperation between Korea and Japan, this study foresees an era of new dynamics surrounding historical contentious issues in the Korea-Japan relationship.
\end{abstract}

Key Words: Korea-Japan relations, sex slaves, forced laborer, ideational reconciliation process, transnational litigation

$\mathrm{W}$ hen Korean president Kim Dae-jung and the Japanese prime minister Keizo Obuchi announced the Joint Declaration: A New Korea-Japan Partnership towards the Twenty-first Century in 1998, longtime rivals Korea and Japan seemed to embark on a new and euphoric phase in their relationship. Not only the two leaders but also the many citizens of the two countries expected that future-oriented economic, cultural, and social cooperation issues might characterize Korea-Japan bilateral relations (Lee 2002). However, the expectations of 15 years ago have not been realized perfectly. Examining their clearly strained relationship during the Junichiro Koizumi era, the two countries continued to engage in disputes over lingering historical issues, such as compensation to victims of sexual slavery and forced labor during the Pacific War, top

*Ja-hyun Chun (jahyunchun@gmail.com) is Research Professor at the Graduate School of International Studies (GSIS), Korea University, South Korea. She was previously a post-doctoral fellow at the American Institute of Contemporary German Studies, Johns Hopkins University, USA. Her forthcoming articles will appear in Japanese Journal of Political Science, East Asia, and International Relations of the Asia-Pacific.

Youcheer Kim (youcheerkim@gmail.com) is a PhD candidate at State University of New York at Albany. He received his LLM degree from Washington College of Law at American University. He was previously a graduate scholar at the New York State Assembly.

The Korean Journal of International Studies Vol.12-1 (June 2014), 255-276.

http://dx.doi.org/10.14731/kjis.2014.06.12.1.255

(c) 2014 The Korean Association of International Studies 
Japanese leaders' visits to the Yasukuni Shrine, the history textbook issue, and so on. Following eruptions over several contentious issues, including territorial disputes, many experts deemed that Korea-Japan relations had reached a historical nadir (Lee 2013).

The continuing turmoil in these two mature democratic and capitalist countries is a puzzle to many international relations (IR) theorists. Contrary to predictions made using existing IR theories, continuing shared threat perception against North Korea, the consolidation of democracy in Korea, and the socioeconomic interdependence between the two countries or improving mutual perception have not resulted in a deeper level of reconciliation between Korea and Japan (Cha 2003). In this article I attempt to solve the puzzle by introducing and illuminating on the features of "the ideational reconciliation process." Contrary to existing IR theories that mainly focus on intrinsic characteristics of sovereign states and their transformation, the ideational reconciliation process captures the dynamics created by "people" who are the main actors in the process. By adopting this alternative analytical framework, this article explains how and why Korea and Japan failed to achieve a deep level of reconciliation. Consequently, an era of new dynamics surrounding historical contentious issues in the Korea-Japan relationship is predicted, rather than the unconditional cooperation predicted by liberal theorists.

To demonstrate the salience of the analytical framework and main argument, this article analyzes sex-slave victims' and forced laborers' transnational litigations, who brought in a "rights revolution" as well as new dynamics in KoreaJapan relations. Among many contentious issues between the two countries, the issues of sex slaves and forced laborers during the Pacific War are particularly worthy of attention for their significant policy implications, analytical value, and unique nature. Although "symbolic" historical issues, such as Japanese prime ministers' visits to the Yasukuni Shrine, descriptions in middle and high school history textbooks, and the historical origin of the effective control of Dokdo Island, have a significant effect on the politics of memory and identity in the two countries, the issues of sex slaves and forced laborers are qualitatively different from these issues. Visible actors/victims and associated support groups of these two issues make them not only a matter of identity and memory, but also an area of "political demand" and accommodation that fundamentally should be solved through diplomatic and legal channels (Shin and Sneider 2011). In other words, the existence of victims makes it difficult for the two governments to skillfully manage public opinion and gain popularity in the manner adopted for other historical issues since the nature of the issues demand more than rhetoric.

The victims who have long been marginalized in Korean politics and at the 
diplomatic table between Korea and Japan have tried to achieve their own "rights revolution" in the courtroom. Their efforts ultimately resulted in two landmark decisions of the Constitutional Court and the Supreme Court of Korea. The Korean government's recent policy transformation and an assertive stance on two historical issues, in this regard, are distinguished from the previous government since it was motivated not only by public opinion, but also by the Constitutional Court and the Supreme Court of Korea. Against this backdrop, in this article I analyze the sophisticated features of a flawed ideational reconciliation and the rights revolution of the victims within it.

\section{COMPETING THEORIES AND ALTERNATIVE THEORY-BUILDING TO EXPLAIN THE CYCLE OF KOREA-JAPAN RELATIONS}

Despite the long and sincere efforts for reconciliation as the joint declaration in 1998 illustrates, few researchers would answer with a firm "yes" on the question, “Have Korea and Japan genuinely reconciled?” During the Cold War era, even the question itself was not highly salient as the contentions between Korea and Japan had been submerged under the Cold War structure, and the shared threat perception against the Communist Bloc. By sharing the security umbrella provided by the United States, Korea and Japan formed two pillars of a de facto triangular alliance in the Northeast Asian region (Cha 1999). After the demise of the Cold War structure, however, the deep-rooted antagonisms of these two mature democracies frequently erupted, resulting in severe diplomatic contentions despite a high level of interdependence in social, economic, and cultural exchanges between civilians. The Korea-Japan relations in the post-Cold War era is so delicate and complicated to the extent that none of the three main IR theories - realism, liberalism, and constructivism - can provide a coherent and compelling explanation on it. In general, these theories are over-deterministic. They tend to become absorbed with a certain key variable or issue area, and thereby fail to explain the 'cycle' of contention and cooperation in the Korea-Japan relations.

To begin with, realists view that the structural anarchy characterizes international relations, and presume that survival is the most important motivation behind sovereign states' external behaviors (Waltz 1979). As a logical consequence of the security-driven anarchical assumption, for realists the overarching alliance system with the United States is still a critical factor or amalgam for the bilateral relations between Korea and Japan. Although the Cold War structure had gone, the historical legacy of 'virtual alliance' facilitates security cooperation between Korea and Japan, as long as the threat from North Korea is present (Cha 
1999). Contrary to realist predictions, the functional necessity of security cooperation has not paved a path toward harmonious bilateral relations. More than any other empirical evidence, the political firestorm that was ignited by the proposed Korea-Japan military pact during Korea's Lee Myung-bak administration vividly demonstrates the deep historical animosity between the two countries, which deters long-term cooperation and creates a continuous cycle of contentions and cooperation (Choe 2012).

Liberal theory also has only limited explanatory power to explain Korea-Japan relations in the post-Cold War era. The gist of liberal IR theory, despite its many variants, is epitomized by Kant's tripod, which assert: "democratic polity, economic interdependence, and international law, considered together, can bring in peaceful relations among countries" (Russette 2001, 35-42). The Korea-Japan dyad, on its face value, satisfies the preconditions of Kantian peace. The Polity IV dataset, which is one of the most popular datasets to measure the level of democracy in many IR and comparative politics studies, classifies both Korea and Japan as full democracies by giving each " 8 " and ' 10 " on a 21-point scale ranging from "-10" (hereditary monarchy) to " +10 " (consolidated democracy) (Gurr and Marshall 2011). The trade amount between the two countries reached $\$ 108$ billion in 2011, and Japan remained the third largest exporting market, while Korea was also ranked as the third largest exporting market to Japan (Ministry of Foreign Affairs of Japan 2012). The two countries also share the rule of tradition and joint membership in many international organizations. The Affinity of Nations data, measuring the level of policy congruence in the United Nations (UN) General Assembly, gives the score of " 1 " (most similar interest) for the Korea-Japan dyad from 1997 to 2002 (Garzke 2005). In addition to the shared security concerns over North Korea and chronic anxiety over the U.S. commitment to East Asia, these shared liberal components caused many IR scholars and policymakers to have strong convictions regarding the future relations between Korea and Japan. Immediately after the declaration between President Kim Daejung and Prime Minister Keizo Obuchi, some IR scholars asserted that "the development of relationship between Korea and Japan may offer one of the best examples of historical reconciliation in the region" (Cha 1999, 38).

Even if the two countries have never engaged in military disputes since Korea's independence in 1945 and the demise of the Cold War in the 1990s, few IR scholars and citizens of both countries would frame it as a "peaceful relationship," considering the frequent eruptions of high diplomatic contentions described above. Roh Moo-hyun, the successor to Kim Dae-jung, even initiated a "diplomatic war" against Japan for the dispute instigated by the Japanese Prefecture Council's Memorial Day on the Dokdo islands, which have historically been controlled by 
the Korean government (Yonhap News 2005). Although the Lee Myung-bak administration (which succeeded the Roh Moo-hyun government) relatively acquiesced on the contentious issues such as sex slavery and forced labor in the early period of his administration, the cycle of contentions recurred in the later period of his administration. President Lee framed the sex slave and forced labor issues as universal human rights and women's rights, and strongly rebuked the Japanese government's inaction (Chosun Daily 2012). His visit to Dokdo Island - the first time for a national leader -also provoked a protest from the Japanese government. In response to Lee's visit, the Japanese government suspended the annual summit dialogue with Korea and even considered withdrawing the won-yen currency swap agreement (Lee 2012). Although many signs of improvement in Korea-Japan relations should not be underestimated, the cyclic eruptions of severe diplomatic contentions render liberal IR theory's optimistic expectations merely a qualified claim.

The constructivist approach, in comparison with realism and liberalism, can relatively better explain Korea-Japan relations in the post-Cold War era by shedding light on the issue of 'identity' and 'collective memory' (Berger 2007). Constructivists believe that anarchy in the international system is "socially constructed" by states and accept the possibility of its gradual transformation (Wendt 1999). In the analysis of Korea-Japan relations, some constructivists focus more on positive empirical evidence such as improving mutual recognition, whereas pessimistic constructivists highlight grudging historical animosity (Park 2009). Even if constructivists capture more relevant variables, contrasting theoretical arguments, fragmented empirical evidence, and conceptual ambiguity, and difficulty in empirical testing makes the constructivist argument mere theoretical conjecture, rather than a sophisticated analytical framework.

Considering the limited explanatory power of the three main IR theories, in this article I suggest an alternative analytical framework called the 'inter-state reconciliation model'. Inter-state reconciliation can be defined as "changing a hostile relationship between two nations in conflict to a friendly and harmonious one" (Ackermann 1994, 229). The level of reconciliation can be conceptually classified from the weakest to the strongest according to Crocker's three levels of reconciliation theory. The shallowest level, in Crocker's classification, exists when there are no further injuries or killings between the hostile parties and basic law is observed. The intermediate level of reconciliation can be observed when two parties recognize and respect each other despite lingering differences and conflicts. At this stage, the two parties are able to understand each other through dialogue, and begin to carry out negotiations in areas of mutual interests. The deepest level of reconciliation can be observed when two parties share broad visions, mutual 
treatment, recovery, and forgiveness (Crocker 1999). As evaluated by Crocker's analytical framework, Korea-Japan relations have failed to move into the deepest level, and instead are stalled at the intermediate level.

The reconciliation process can also be classified into three stages by main focus and agendas: procedural, material, and ideational reconciliation. As a bilateral relationship evolves, the agenda in the talks between the two countries tends to develop from procedural to material and from material to ideational. In other words, the evolution from procedural to ideational reconciliation is an obvious signal indicating a deep level of reconciliation. Empirically, many experts consider the Germany-Poland dyad an ideal example, which evolved to the ideational reconciliation stage in the 1960 (Chun 2012).

Procedural reconciliation is the first stage of reconciliation, which begins with the signing of a peace treaty or agreement, and can be defined as a written agreement between two or more hostile parties to formally end a war (Kunz 1952). There are various terms used to explain this early stage of relationship-building, including "recognition," "establishment of diplomatic relations," and "normalization of relations." Similar to a peace treaty, these all take place in the earliest stages of reconciliation between hostile countries. In the case of reconciliation between a former colonizer and colonized country, state recognition is a symbolic starting point of reconciliation as a former colonial ruler acknowledges its colony's independence and accepts it as a sovereign state. After the approval stage, the two countries move into establishing diplomatic relations, which is usually formed by two equal nations. Once diplomatic ties are established, it usually leads to the installment of an embassy and an exchange of diplomatic missions.

The second stage is a material reconciliation, which occurs when economic exchange takes place between two formerly hostile countries. At an initial stage of reconciliation, there are some types of economic cooperation, which particularly facilitate and consolidate the reconciliation process. Depending on the degree of spillover to reconciliation as an amalgam in state-to-state relations, the specific type of reconciliation can be classified as a passive type or an active type. The most passive form of material reconciliation is economic cooperation and procurements of foreign aid. Economic cooperation refers to the transfer of both private and public capital between countries, including official development assistance (ODA) and other government, private and non-government funds.

The passive type of material reconciliation, in the context of rapprochement between bete noires, merely highlights compassion and morality of donors, whereas the grudges accumulated during war or colonial-rule are submerged. The passive type of material reconciliation, therefore, rarely has significant ramifications on the ideational reconciliation process. More active forms of material 
reconciliation are "claims" and "reparations," which presume the responsibility of wrongdoers. Originating from the Versailles Treaty after World War I, reparations functioned as a partial solution for the civilian casualties incurred during the war and the lingering emotional grudges held because of them. A distinction from the traditional inter-state compensation, the Versailles Treaty and many other treaties justified financial compensation between individuals and the state. The active form of material reconciliation, such as reparation and acceptance of it, connotes strong moral implications, including apologies and atonement for past crimes.

The third stage of reconciliation is ideational reconciliation, which takes place when parties do not attempt to distort or hide the dark side of the past and redirect their relations to future-oriented relations. A symbolic act of leaders, a verbal apology, a publication of a history book with a shared interpretation on a core bone of contention, and the establishment of memorial halls and museums, are illustrative examples of actions for ideational reconciliation. When ideational reconciliation is consolidated, disagreement over historical perceptions would not be a salient issue in the bilateral relationship between states. One intrinsic difference between ideational reconciliation and procedural or material reconciliation is that a sovereign state does not necessarily monopolize or dominate the ideational reconciliation process. Whereas an agreement or treaty with domestic ratification finalizes the political discourse on the procedural and material reconciliation, there is no such watershed demarcated by a sovereign state in the ideational reconciliation process since a perception on a historical issue and foreign country has an evolving and ongoing nature. The ideational reconciliation, therefore, is usually a fragmented, slow, and incremental process in which state and non-state actors are intertwined, and it is sometimes facilitated by accommodative actions of perpetrators of wrongdoings (Kriesberg 1998). Likewise, an inter-state agreement is a sufficient condition for procedural and material reconciliations, whereas ideational reconciliation requires a majority of people's genuine agreement and commitment to a shared idea.

The fragmentation among procedural, material, and ideational reconciliation is particularly salient in a dyad that includes a non-democratic regime, since there is a higher probability of a gap between people's perceptions on the legitimacy of the reconciliation process. In a reconciliation process between a democratic and an authoritarian regime, the autonomy of the authoritarian regime from its people tends to facilitate a procedural or material reconciliation by suppressing people's grudges on a premature reconciliation without sufficient accommodative actions from a former enemy. This type of fragmentation is particularly conspicuous in the case of Japan's reconciliation diplomacy as the following section of 
this article illustrates, and it is a root cause of the recurring cycle of diplomatic tensions with Korea.

The gist of the ideational reconciliation model, again, lies in its fragmented actors, including "people" inside a sovereign state. Some contemporary IR theorists have already articulated the importance of sub-state actors in many contexts of international relations (Milner 2009). On the issue of perception and ideational conflicts, public diplomacy has been regarded as a salient state policy to infiltrate other countries' borders and attract people's support on certain policy positions, as the Figure 1 well illustrates (Nye 2008). In terms of the complex interaction among multiple actors infiltrating a state border, the ideational reconciliation and public diplomacy share common features. The ideational reconciliation, however, mainly concerns a bilateral perception on controversial historical issues, whereas public diplomacy refers to a unidirectional policy stance of one country to another country and society on broader issues. From the perspective of "people," who constitute the core constituents of ideational reconciliation, as well as public diplomacy, the diplomatic table of Korea-Japan has long neglected and excluded pivotal constituents, and is, thereby, fundamentally flawed. In addition to the explanation of the recurring diplomatic contentions, this flawed ideational reconciliation process also explains the failure of Japan's public diplomacy with its neighboring countries, as indicated by existing literature (Nakamura 2013).

Figure 1. Salient Sub-State Actors in the Ideational Reconciliation Politics

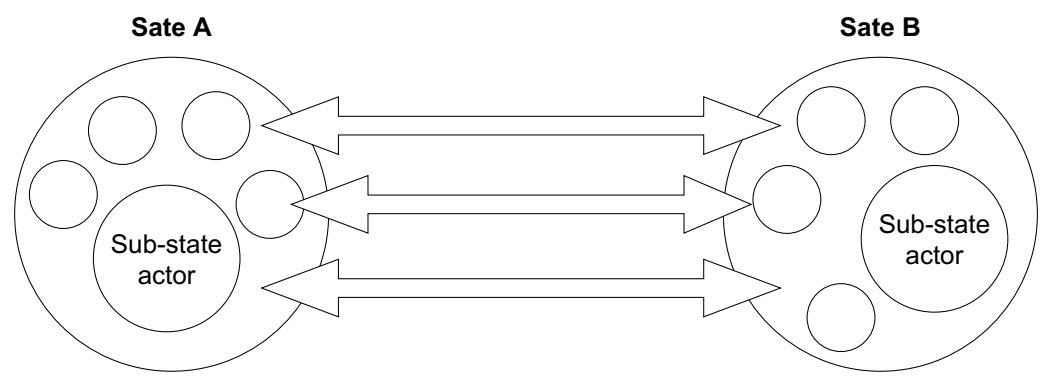

\section{FLAWED IDEATIONAL RECONCILIATION AND THE RIGHTS REVOLUTION OF VICTIMS: PHASE I}

The exclusion of core constituents from the reconciliation process dates back to immediately after Korea's independence and the normalization of diplomatic 
relations between Korea and Japan. After those critical moments, strong path dependence characterized the political dynamic on the issue of sex slaves and forced laborers. Particularly, Korea, as a small state under the Cold War structure and its people under dictatorial rule, had been totally excluded from the discourse on reparations and marginalized in the reconciliation process and the process of diplomatic normalization. This flawed procedural reconciliation process at both the international and domestic level, in the end, is a root cause of why victims under Japanese colonial rule were politically marginalized, and why they had to rely on a juridical body for their rights revolution through transnational litigations.

To begin with, Korea was not invited to the San Francisco Peace Treaty of 1952, and thereby lost a legitimate opportunity to pressure Japan for a genuine ideational reconciliation. The San Francisco Treaty was signed by the Allied Powers and Japan to officially end World War II on the Pacific front, despite its strong wish and demands. Recognizing the threat of an emerging Cold War structure and the strategic importance of Japan as a bulwark against the Soviet Union, the United States suppressed Korea's demands for reparations, which could have been a serious burden for Japan's economic revitalization (Lee 2008).

As the postwar dealings of colonial rule were eliminated from the treaty, the agenda was left for bilateral discussions between Korea and Japan, and the long 14 years of tough dialogue began. The first Korea-Japan bilateral meeting for diplomatic normalization was held on February 15, 1952, and resulted in a turbulent confrontation. In the negotiations, the Korean government focused on "reckoning the past," whereas the Japanese government insisted on "establishing new relations" (Lee 2008, 18-20). Notable progress was made in the sixth round of talks in 1961, in the year when General Park Chung-Hee established his regime by coup d'état. At the confidential talks held on November 12, 1962, the then Chief of the Korean Central Intelligence Agency, Kim Jong-pil, and Japanese Foreign Minister, Masayoshi Ohira, compromised on war reparation payments and the status of Koreans, which established the basic framework for the treaty in 1965. As a result, the two countries signed the Treaty on Basic Relations and four supplementary agreements, including the problematic "Korea-Japan Claim and Economic Cooperation Agreement" (hereinafter, the Claim Agreement). Article 1 of the Claim Agreement stipulates that Japan will provide Korea with a \$300 million grant and a $\$ 200$ million credit line. As a quid pro quo, Article 2 confirms that "property, rights, and profits between Korea and Japan, as well as claim issues related to both countries and its people have been completely and ultimately settled" (Lee 2008). ${ }^{1}$

As the agreement did not entail a sincere apology and nor expected reparations 
to Korean victims who suffered brutal colonial ruling by Japan, the flawed agreement fanned Korean people's nationalism, resulting in highly intense demonstrations to the extent that Park Chung-hee's regime had to declare martial law. Park's regime, to mitigate dissatisfaction, passed a domestic law for the compensation to victims of forced labor. However, Park's administration merely distributed $5 \%$ of the reparations from Japan to Korean forced laborers who had unpaid salaries from the Japanese government (MBC Documentary 2001). At this time, the issue of sex slaves was not even well-known in Korean society.

The victims of sex slavery and forced labor, whose voices were unheard at the diplomatic table, had to rely on transnational litigations for the protection of their compensation rights and coalition building. The process can be conceptualized as "the rights revolution," which can be defined as a substantial transformation in social perception on minority or marginalized people's rights, and social awareness and acceptance on the problem of historical discrimination. Under the flawed reconciliation politics, which excluded and marginalized victims, the only accessible venue to marginalized people was the judicial system. The political function of the court system, in a country with a tradition of consolidated rule of law, lies in the protection of individuals' rights against illegitimate state power and even against majoritarian dictatorship. There are some preconditions for rights revolution through legal channels, such as the constitutional guarantee of rights, judicial leadership, and popular rights consciousness. In a country that satisfies these preconditions, a minority will frequently select the judicial system for initiating the rights revolution since a legal game in the courtroom deems jurisprudence salient as a golden rule when deciding winners and losers, whereas the majoritarian rule is the rule of thumb in a political game. The intrinsic advantages of court made many minority groups select court as an appropriate venue to initiate a rights revolution, and the advancement of minority groups' rights have been achieved in many empirical cases of several countries (Epp 1998).

In the case of sex-slave and forced-laborer victims, they could initiate the process only after the democratic transition of Korea, which satisfied such preconditions. After the transition, the victims started to utilize the same incentive structures and pursued their rights revolution through the court system. One noteworthy difference of rights revolution for victims under the Japanese colo-

\footnotetext{
${ }^{1}$ Agreement Between Japan and the Republic of Korea Concerning the Settlement of Problems in Regard to Property and Claims and Economic Cooperation Article 2, The World and Japan Database Project (November 14 2012), accessede at http://www.ioc.u-tokyo.ac.jp/ worldjpn/documents/indices/JPKR/index-ENG.html (May 18, 2014).
} 
nial rule from other types of rights revolution lies in its international characteristics. More often than not, perpetrators of crimes who are the target of litigation are a foreign government or foreign companies in the case. This fairly limits the international characteristics of the issue of res judicata of one country's court, and thereby makes a process of rights revolution more complicated. In a similar vein, because inter-state ideational reconciliation requires penetration of a sovereign state's border, a victory in one country's court will not necessarily initiate expected genuine social changes if it does not appeal to people's minds in the target country.

Considering the uniqueness and complexities of the issue, transnational litigations in Korea and Japan was an optimal strategy for the victims of sex slavery and forced labor. The first target was naturally the Japanese court. Japan, as a direct perpetrator of human rights abuses, holds the key for the solution of contentions, as well as material resources for distributing compensation to the victims. There have been over 60 litigations on the sex slave and forced labor issues in the Japanese court, with substantial support from the Association of Attorneys Considering Compensation Issues by Japan. In December 1991, when the sexslavery issue started to become known in Korean society, Kim Hak-sun and two other survivors filed the first lawsuit against the Japanese government in the Tokyo District Court. The court dismissed the case due to the extermination of individual claims by the Korea-Japan Claim Agreement (Ishikane 2006).

After Kim's challenge, many similar cases followed suit. Particularly, the Japanese court's jurisprudence in the Song Shin-do case strongly foreshadowed the jurisprudence in many cases to follow. In this case, Song Shin-do, another victim of sex slavery, filed a similar suit pursing an official apology from the Japanese government and 1.2 billion yen in compensation. The main causes of action and legal issues addressed in this case were: 1) whether the Japanese Military's atrocious actions were against the jus cogens and widely recognized customary international principles, and whether such violations make plaintiffs eligible to initiate a suit; 2) whether the Japanese government was liable for compensation under the civil law clause 723; and 3) whether the Japanese government and Japanese Diet's act of omission makes the state a tortfeasor (Japanese District Court of Tokyo 1999).

Put simply, in its verdict, the court rejected all claims of the plaintiff and dismissed the case. Concerning the first issue, the court delivered that on deliberating whether the Japanese government's actions constituted a violation of the jus cogens was not meritorious. The court rigorously drew a line between standing issues and legal evaluation of the state's action, and concluded that violations on jus cogens do not automatically confer a rights standing upon a victim. To the sec- 
ond issue, the court denied that the Japanese government had a legal obligation to provide compensation to the victims of state actions before the adoption of the National Compensation Law. The court also rejected the plaintiff's claim on the third issue since no specific higher laws obligate the Japanese government to enact a law for compensation. The Japanese government's jurisprudence in the Song Shin-do case, which skillfully muddled the plaintiff's claims, was repeated in many cases to follow.

The only successful result for the sex-slaves victims was ruled by the Lower Court of Shimonoseki (Japanese District Court of Yamaguchi 1998). The plaintiffs' claims and cause of actions were very similar to Song Shin-do's case, but the court arrived at a different conclusion on the issue of the state's responsibility. Although the court rejected the victims' standing in the case and the Japanese government's duty of compensation under the clause of the Japanese Constitution, the court held that the Japanese Diet had a responsibility to pass a special law for compensation, considering the massive human rights violations that victims endured. The Shimonoseki Court's decision was significant in the sense that it behooved the Diet for action, although took a passive stance on the interpretation of the Korea-Japan Claim Treaty and the right of peaceful coexistence under the Japanese Constitution. The decision, however, was reversed in the higher court and the expected political pressure through the litigation did not substantially materialized (Naito 2005).

The litigation by forced laborers encountered similar legal barriers and failed to initiate a process for compensation or exert significant political pressure on the Japanese government. One important point worthy of attention is that American prisoners of war who were forced into labor camps by the Japanese government also initiated litigation in the Japanese court, which makes it difficult for the US government to take the position of beholder. Although a slightly different set of issues, this did not influence the decisions of the Japanese court, and most of the cases, including those by Korean victims, were dismissed, mainly due to the dominant jurisprudential grounds that the San Francisco Treaty and the Korea-Japan Claim Treaty settled the individuals' claim issues (U.S. Law Library of Congress 2008). In a few cases, however, the Japanese court confirmed that the Japanese government and some private companies were legally liable, and had a duty to compensate victims of forced labor. As an illustration, in the Ukishimamaru case, in which a Japanese ferry carrying over 7,00o Korean forced laborers sank with 549 casualties, the court's verdict ruled that the Japanese company acted against its duty for safely returning Korean forced laborers, and 300 million yen was awarded to each victim (Shim 2001).

Litigations in the Japanese court, in general, failed to ignite significant political 
and social change, not to mention failing to find a real legal remedy for the victims, mainly due to the traditionally weak judicial review and rights-consciousness in Japan. The Japanese court is notorious for its passivity to intervene in political situations and to deliver a verdict against state actions (Law 2011). Japanese people are relatively passive about challenging the government to protect their individual rights, and as a result, are destined to be less sympathetic to litigations by foreigners on an issue from five decades ago.

For some compelling reasons, the U.S. court was regarded as a good alternative venue to the Japanese court for the sex-slave and forced-labor victims, whose demands were not satisfied in Japanese courts. To begin with, the U.S. court, due to its unique legislation of the Alien Tort Claims Act (ATCA), allowed litigations by foreign nationals against foreign nationals, even if a problematic action was not perpetrated in a U.S. territory in many cases. The ATCA stipulates that "the district courts shall have original jurisdiction of any civil action by an alien for a tort only, committed in violation of the law of nations or a treaty of the United States" (Alien Tort Claims Act 1789). Through this legal channel, many foreign nations brought torts claims against other foreign nationals in the U.S. courts and won many cases (DeNae 2006). The Korean sex-slave and forced-laborer victims could also utilize this legal channel in the U.S. court against the Japanese government.

Second, the evolutionary path of ideational reconciliation between the United States and Japan on the Pacific War functioned as an effective pretext or frame of reference for Korean victims. The United States, as illustrated above, abandoned their rights of reparations for strategic reasons in the state-to-state level. At the same time, the United States has exerted sincere efforts for the ideational reconciliation of human rights abuses perpetrated against approximately 120,000 Japanese Americans, who were imprisoned in the internment camps during the Second World War. From approximately 1988, the U.S. government has taken many actions to redress the internment issues, including a detailed acknowledgement of the violation of fundamental liberties, a presidential apology, individual reparations, and far-reaching public education (Yamamoto and Lee 2012). These efforts for embracing the dark-side of history and achieving restorative justice puts the U.S. government in a morally superior position to push the Japanese government to exert similar efforts toward Korea.

Third, the United States has always been a relevant third party in the KoreaJapan reconciliation process from the moment of the San Francisco Peace Treaty and the Diplomatic Normalization Treaty. Mainly motivated by security reasons, the U.S. government has long tried to clamp down on excessive outbursts of Korean antagonism against Japan, while also constraining the excessive out- 
bursts of Japanese nationalists, both of which could be perilous to the triangular security cooperation in Northeast Asia (Park 2011). Without transforming the U.S. stance, which has abetted two governments' silence and neglect on two issues, the realization of restorative justice could not have been expected. If litigations by victims could trigger the awareness of the American people on the issue, as well as political and diplomatic pressures on the Japanese government, there could be no better way of triggering a transformation of the U.S. stance than litigation in the U.S. court. These reasons, considered in conjunction, brought more than 100 cases related to the Japanese government and private companies' legal liability and compensatory obligations for human rights violations during the Second World War to U.S. courts.

Among them, the case brought by Hwang Geum-joo and 14 other victims of sex slavery significantly affected following cases as a main precedent (U.S. Court of Appeal 2005). This case was filed in the district court of the District of Columbia (DC), and was ultimately dismissed, mainly due to immunity given to the forging government by the Foreign Sovereign Immunity Act (FSIA), which mandates "presumptive immunity for foreign nations from lawsuits brought in the US" (Foreign Sovereign Immunity Act 1976). Although the plaintiff's advocate invoked the exception of FSIA for the reason of commercial activity, the court did not accept the claim. The court also framed the pending case under the political doctrine and ultimately dismissed the case, thereby almost closing the door for further litigations (Lee 2003). Although the U.S. court's stance was criticized from many sides, the recent jurisprudential trends to restrain the scope of ATCA made it difficult for the U.S. court to accept the claims of the victims' counsel.

To muddle through the legal barriers of FSIA, the victims of forced labor targeted Japanese companies for their compensation claims, rather than targeting the Japanese government. In Choe v. Nippon Steel Corp, Kim v. Ishikawajima Harima Heavy Industries Co, Ltd, and Sung v. Mitsubishi Corp, which were filed in the Northern District of California, the court dismissed the cases, mainly due to the limitation of subject matter jurisdiction, which exclusively delegates diplomatic issues to the Federal government and the termination of individual claims under the San Francisco Treaty and Korea-Japan Claim Treaty (U.S. Court of Appeal 2001). Although the plaintiffs changed the target and cited different jurisprudential grounds, the negative end result was similar in these cases.

The litigations in the United States, however, facilitated a political coalitionbuilding for the solution of two critical issues and exerted intense pressure on the Japanese government. The U.S. House of Representatives, proposed by Congressman Michael M. Honda from Hawaii, passed Resolution 121, which demanded that the Japanese government "formally acknowledge, apologize, and 
accept historical responsibility in a clear and unequivocal manner for its Imperial Armed Force's coercion of young women into slavery" (U.S. House of Representatives 2007). ${ }^{2}$ To Asian-American political leaders, such as Honda, the historical issues were so critical to the extent that taking an assertive action was inevitable for appealing to his constituents.

\section{FLAWED IDEATIONAL RECONCILIATION AND THE RIGHTS REVOLUTION OF VICTIMS: PHASE II}

To the sex-slave and forced-labor victims, litigations in the Korean court were regarded as a last resort, as well the most ideal forum to initiate rights revolution. The Korean Constitutional Court, despite its relatively short history, has been touted as a good example for other courts in young democracies to follow. With the consolidation of democracy and the rule of law tradition in Korea, the Court has exerted significant influence on many judicial and political issues to the extent that the trend of "judicialization" of Korean politics emerged as a buzzword among many scholars. The authority enshrined in the Korean Constitutional Court was affirmed in some symbolic political cases, such as the decision to impeach former President Roh Moo-hyun and a dispute over relocation of the Korean Capital. The Court also played a leading role for consolidating and raising the consciousness of many individual rights, such as labor, the environment, and human rights (Park 2008). As the Korean Constitutional Court has imposed a relatively low barrier to civil rights cases, the ratio of individual rights cases to all cases is astonishingly high at $96.2 \%$, which is a clear indication of strong constitutionalism.

The victims, in their initial litigations before the Korean Constitutional Court, targeted the trepid Korean government, particularly the Ministry of Foreign Affairs and Trade (MOFAT) for a resolution to the issue (Korean Constitutional Court 2011). The victims asserted that the Korean government's act of omission significantly violated their constitutional rights of being protected by the government as stipulated in Article 2 Section 2 and Article 10. Specifically, the attorney for the victims indicated that Article 3 of the Claim Agreement, which stipulates on the dispute-settlement through arbitration panel if disagreement over inter-

\footnotetext{
${ }^{2}$ U.S. House of Representative, Res. 121 (110th), "A Resolution Expressing the Sense of the House of Representatives That the Government of Japan should formally acknowledge, apologize, and accept historical responsibility in a clear and unequivocal manner for its Imperial Armed Forces," accessed at https://www.govtrack.us/congress/bills/110/hres121/text.
} 
pretation on a treaty occurs, obligates the Korean government to purse such a channel. As the Japanese government's authoritative interpretation of the Claim Agreement has always been a barrier in transnational litigations, purveying the Korean government's jurisprudence through the diplomatic channel was a necessary step for a resolution to the issue, as well as ideational reconciliation between Korea and Japan.

The Korean Supreme Court, following the Constitutional Court's suit, delivered a monumental ruling on the forced laborers. In this case, the Supreme Court filed a suit against Mitsubishi heavy industrial, a Japanese conglomerate, which extensively exploited laborers during the Second World War. The court shared the Constitutional Court's perspective on the Claim Treaty and viewed that the treaty itself did not terminate individuals' claims before the Korean court. The court decided that the economic aid provided by the Claim Agreement under Article 1 was not a quid pro quo to the abandonment of the claims in Article 2, and that the Japanese government's denial of liability over colonial rule during negotiations demonstrates that torts and individual compensation was not a subject of the Claim Agreement.

The Supreme Court could arrive at this conclusion by denying the res judicata of decisions held by the Japanese courts, which were accepted as valid decisions in the lower court. To deny the lower court's jurisprudence, the Supreme Court made a rigorous analysis of Clause 217 of the Korean Civil Procedural Law, which stipulates, "A final and conclusive judgment by a foreign court shall be acknowledged to be valid, only upon the entire fulfillment of the following requirements: (3) That such judgment does not violate good morals and other social order of the Republic of Korea." The Court pinpointed that the Japanese court's decisions assumed that Japanese colonial rule and mobilization of Korean forced laborers were legitimate, which is in direct contrast to the preamble and ethos of the Korean Constitution. The Supreme Court, thereby, reversed and returned the case to the lower court for further review (Korean Supreme Court 2012). The Ministry of Foreign Affairs (MOFA) established a task force team to implement two symbolic cases, and the team has exerted efforts to establish a strategy for the new round of negotiations with the Japanese government. Considering the consolidated rule of law tradition and social ramifications of the case, the MOFA may not be able to take a lukewarm stance on the issue any longer. The litigations by victims in the Korean court resulted in the most tangible results. 


\section{LIMITATIONS OF TRANSNATIONAL LITIGATIONS AND PROSPECTS FOR ITS EFFECT ON KOREA-JAPAN RELATIONS}

The recent phase and trend of transnational litigations, despite its contribution to rights revolution from the court, has conspicuous political externalities. More than anything, the size of the win-set in a negotiation between Korea and Japan for the resolution of issues became narrower as the door of the Korean government's political maneuverability was closed by two symbolic court cases. It is widely known that a negotiator sometimes even intentionally adopts the "tied hands" strategy to constrict the domestic win-set, which usually results in increased bargaining power, as well as higher risks of a deadlock in a negotiation (Evans 1993). Although the Korean government has not intentionally adopted the "tied hands" strategy in this case, two monumental cases by judicial bodies introduced exactly the same effects as the act of omission is not a viable strategy, but an unconstitutional state behavior.

Figure 2 well illustrates the expected policy shift of the Korean government triggered by court decisions. Km symbolizes the negotiating point in which the Korean victims' rights and interests are best protected, whereas Jm shows the Japanese government's stance to navigate through two difficult issues. Historically, the external pressures exerted by the United States and Korean government's authoritarian polity, considered in conjunction, made the negotiating point fall into the position somewhere between $\mathrm{K}_{1}$ and $\mathrm{J}_{3}$ in favor of the Japanese side. The Korean courts' two symbolic decisions tied the Korean government's hands and shifted its position toward the optimal point of victims' rights.

Figure 2. The Expected Policy Shift of Korean Government on Two Issues

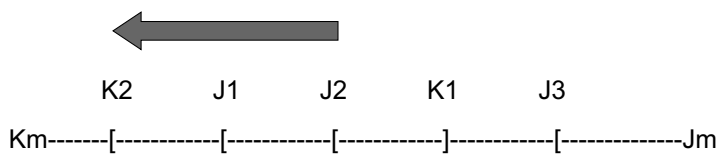

The expected policy shift, however, can have detrimental effects on the overall relationship between Korea and Japan as the decreased win-sets for the negotiation can perpetuate the deadlock. Particularly, a negotiation with the conservative Liberal Democratic Party (LDP) of Japan, whose fundamental stance on the issue falls somewhere between the point of $\mathrm{J}_{1}$ and $\mathrm{J}_{3}$ at best, might be extremely difficult as the newly elected Prime Minister Shinjō Abe directly rejected any legal liability of the Japanese government on the historical issues. Prime Minister Abe, as his macroeconomic policy shows in the short-term results, enjoys a high 
approval rating of approximately $70 \%$ and propels the strong nationalism to mobilize Japanese people.

The Democratic Party of Japan (DPJ), whose strategic leverage could potentially fall to the $\mathrm{J} 1$ point, was substantially marginalized and lost meaningful checks-and-balances on diplomatic issues. Prime Minister Abe is also encountering an even more extreme hardline, such as the Japan Restoration Party. Tōru Hashitomo, the joint leader of the party and mayor of Osaka, as an illustration, irritated many Koreans and people around the world by his abusive analogy, comparing the victims of sex slavery to prostitutes. He further asserted that prostitution around military camps is also pervasive in the U.S. military camps in Japan. His flippant remarks were harshly rebuked by the Korean mass media and even by a high official of the U.S. State Department. Considering the LDP's strategic necessity to mobilize people through nationalistic sentiment and power-dynamics within the Japanese Diet, the win-set given to the Japanese Ministry of Foreign Affairs is not likely to throttle back into the point of $\mathrm{J} 1$.

With regard to the Korean Court's symbolic decisions on two critical issues, the Korean side pressures a prompt and complete implementation of it whereas the Japanese side reiterates their original legal arguments, as Chief Cabinet Secretary Yoshihide Suga remarked right after the ruling, "the issue of compensation claims between Japan and South Korea has been settled" (Suga 2013). The recent standoff between the Park Geun-hye administration and Shinjo Abe also demonstrates the shadow of narrowed win-set. Two leaders, unlike their predecessors, have never had an official bilateral summit neither in Seoul nor Tokyo. President Park's callous attitude to Prime Minister Abe's welcome remarks spoken in Korean in the trilateral summit in the Hague symbolizes the deteriorated KoreaJapan relations (Lee 2014). Likewise, Korea-Japan relations are likely to hit another nadir as long as the recurring cycle of fluctuations caused by historical issues in the two countries' relations do not make an astonishing exception.

\section{CONCLUSION}

The evolution of Korea-Japan relations and Korean sex-slave and forced-labor victims' rights revolution have demonstrated that states do not necessarily monopolize the ideational reconciliation process. Contrary to the procedural and material reconciliation process, constituents of sovereign states, its people, play an important role in accomplishing the deep level of ideational reconciliation, mainly due to its nature. The victims of sex slavery and forced labor, their support groups, and compassionate Korean citizens, have always been a veto group 
on the Korean government's materials-centric reconciliation policy. These people, who were long neglected and marginalized in Korean politics, and the diplomatic forum between Korea and Japan, at last succeeded in firmly binding the Korean government's stance on two critical historical issues.

The reconciliation process between Korea and Japan analyzed above also demonstrates that the liberal IR theory needs to be a more qualified claim, at least to explain the Korea-Japan relations. Contrary to the euphoric expectation in the late-1990s, the democratic transition of Korea and the socioeconomic interdependence between the two countries has not fundamentally ameliorated the animosity of Korean people against Japan, which remains as a big stumbling block to achieving the deep level of ideational reconciliation. The transnational litigations and victims' achievements in the Korean court, despite their praiseworthy results on face value, have substantially narrowed the size of win-sets in the diplomatic forum between the two countries. Unless top leaders of Korea and Japan clearly understand the narrow size of win-sets on critical issues and take reconciliatory action, the political deadlock between two countries is likely to stay.

\section{REFERENCES}

Ackermann, Alice. 1994. "Reconciliation as a Peace-Building Process in Postwar Europe: The Franco-German Case.” Peace\&Change 19(3), 229-250.

Alien Tort Claim Act. 2013. Findlaw. Accessed at http://codes.lp.findlaw.com/ uscode/28/IV/85/1350 (May 19).

Berger, Thomas U. 2007. "The Politics of Memory in Japanese Foreign Relations." In Thomas U. Berger ed., Japan in International Politics. Boulder, CO: Lynne Rienner, 179-211.

Cha, Victor. 1999. Alignment Despite Antagonism: The United States-KoreaJapan Security Triangle. Stanford, CA: Stanford University Press. . 2003. "Hypotheses on History and Hate in Asia." In Yoichi Funabashi ed., Reconciliation in the Asia Pacific. Washington, D.C.: United States Institute of Peace Press.

Choe, Sang-Hun. 2012. "South Korea to Sign Military Pact with Japan.” New York Times (June 28).

Chosun Daily. 2012. "President Lee Myung-Bak's Address on Independence Day." (August 16).

Chun, Ja-hyun. 2012. "Politics of International Reconciliation: Patterns and Foreign Policy Making of Afflicting States.” PhD Dissertation, Yonsei University. 
Crocker, David A. 1999. "Reckoning with Past Wrongs: A Normative Framework." Ethics \& International Affairs 13(1), 43-64.

Epp, Charles R. 1998. The Rights Revolution: Lawyers, Activists, and Supreme Courts in Comparative Perspective. Chicago: University of Chicago Press.

Evans, Peter B., Harold K. Jacobson and Robert D. Putnam. 1993. Double-Edged Diplomacy. Berkeley, CA: University of California Press.

Garzke, Erik. 2005. The Affinity of Nations: Similarity of State Voting Positions in the UNGA. Accessed at http://dss.ucsd.edu (May 19, 2013).

Gurr, Ted and Monty G. Marshall. 2011. Polity IV. Accessed at www.systemicpeace.org (May 18, 2013).

House of Representative Res. 121 (110th). "A Resolution Expressing the Sense of the House of Representatives That the Government of Japan should formally acknowledge, apologize, and accept historical responsibility in a clear and unequivocal manner for its Imperial Armed Forces" (Passed the House Engrossed Version). GovTrack.us. Accessed at https://www.govtrack.us/congress/bills/110/hres121/text.

Ishikane, Kristl k. 2006. “Korean Sex Slaves' Unfinished Journey for Jusice: Reparations from the Japanese Government for the Institutionalized Enslavement and Massive Military Rapes of Korean Women During World War 2." University of Hawai Law Review 29, 123.

Japansese District Court of Tokyo. 1999. Song Shin-Do v. Japan. 6152 Wa. (Tokyo District Court, October 1, 1999).

Japanese Disctrict Court of Yamaguchi. 1998. Victims of Sex-Slaves v. Japan. 1641 (Yamaguchi District Court, April 26, 1998).

Kang, David and Jiun Bang. 2012. "Japan-Korea Relations: Sisyphus." Comparative Connections 14(1), 129.

Kim, Saeho. 2011. "President Lee Urged the Japanese Government for the Solution of Historical Issues." YTN (December 18). Accessed at www.ytn.co.kr (May 18, 2013).

Kriesberg, L. 1998. Constructive Conflicts: From Escalation to Resolution. Lanham, MD: Rowman and Littlefield.

Kunz, J.L. 1952. "Ending the War with Germany." American Journal of International Law 46(1), 114-119.

Law, David S. 2011. "Why Has Judicial Review Failed in Japan?” Washington University Law Review 88(1), 1428-1433.

Lee, Carol E. 2014. "Current Leaders of South Korea, Japan Meet for First Time." Wall Street Journal (March 25).

Lee, Jae-ho. 2013. "Interview with Professor Chung-In Moon (in Korean)." Pressian(Jan 16). Accessed at http://www.pressian.com. 
Lee, Jung-hoon. 2002. "Interview with Ambassdor Sangyoung Choi." Shindonga (May).

Lee, Sang-deok. 2012. "The Dokdo Dispute and Currency Swap between Korea and Japan." Daily Maeil (October 12).

Lee, Sue R. 2003. "Comforting the Comfort Women: Who can Make Japan Pay?" University of Pennsylvania Journal of International Law 24(1), 509-547. Lee, Won-deg. 2008. “A Study on the Japan's Post-War Reparations Diplomacy: the Perspective of the International Comparisons." Dongbuga Yeoksa Nonchong (in Korean) 22(1), 5-36.

MBC Documentary. 2001. "Now We Can Talk." Seoul: MBC (June 1).

Milner, Helen V. and Andrew Moravcsik. 2009. Power, Interdependence, and Nonstate Actors in World Politics. Princeton: Princeton University Press.

Ministry of Foreign Affairs of Japan. 2012. Korean Economy and Korea-Japan Economic Ties. Tokyo: Ministry of Foreign Affairs.

Naito, Mitsuhiro. 2005. "Postwar Compensation Trials and the Japanese Constitution: Peace, Human Rights of Asia and War Responsibility of Japan." Paper presented at 1st Asian Forum for Constitutional Law (September 24).

Nakamura, Toshiya. 2013. “Japan's New Public Diplomacy: Coolness in Foreign Policy Objectives." Media and Society 5(1), 1-23

Nam, Kijeong. 2008. "Taking Diplomacy Seriously: Japan and Korea on the Road to the Treaty of Peace with Japan." Journal of Northeast Asian History 22(1), 37-71.

NHK Documentary. 2008. "At that Time, History Moved." Tokyo: NHK, June 25. Nye, Joseph S. 2008. "Public Diplomacy and Soft Power." The Annals of the American Academy of Political and Social Science 616(1), 94-109.

Park, Cheol Hee. 2009. "The Pattern of Cooperation and Conflict between Korea and Japan: Theoretical Expectations and Empirical Realities." Japanese Journal of Political Science 10(3) , 247-265.

. 2011. "A Whirlpool of Historical Controversies in Widending Waters of Cooperation." In Marie Soderberg ed., Changing Power Relations in Northeast Asia: Implications for Relations between Japan and South Korea. New York: Routledge.

Park, Jong-hyun. 2008. "The Judicialization of Politics in Korea." Asian-Pacific Law \& Policy Journal 10(1), 63-109.

Russett, Bruce. 2001. Triangulating Peace: Democracy, Interdependence and International Organizations. New York: W.W. Norton.

Shim, Kyusun. 2001. "The Japanese Court Delivered a Symbolic Case on Forced Labors." Donga Ilbo (August 23). 
Shin, Gi-Wook and Daniel C. Sneider. 2013. History Textbooks and the Wars in Asia: Divided Memories. Reprint edition. S.l.: Routledge.

Suga, Yoshihide. 2013. "South Korean Court Orders MHI to Pay Korean Women for Forced Labor." Japan Times (November 1).

Thomas, DeNae. 2008-2009. "Xiaoning V. Yahoo Inc.'s Invocation of the Alien Tort Statute: An Important Issue but an Improper Vehicle." Vanderbilt Journal of Entertainment and Technology Law 11(1), 211-248.

U.S. Court of Appeal. 2001. Kim v Ishikawajima Harima Heavy Industries Co, Ltd. 99-5303. The U.S. District Court of the Northern District of California (September 17). . 2005. Hwang Geum Joo v. Japan. 367 (U.S. App. D.C., 2005).

U.S. Law Library of Congress. 2008. WWII POW and Forced Labor Compensation Cases. Washington, DC : U.S. Law Library of Congress.

Waltz, Kenneth N. 1979. Theory of International Politics. Reading, MA: AddisonWesley.

Wendt, Alexander. 1999. Social Theory of International Politics. Cambridge: Cambridge University.

Yamamoto, Eric K. and Sara Lee. 2012. "Korean "Comfort Women” Redress 2012 Through the Lens of U.S. Civil and Human Rights Reparatory Justice Experience." Journal of Korean Law 11(1), 123-149.

Yonhap News. 2005. "President Roh's Address on KOR-Japan Relations." Yonhap News (March 25). 